\title{
CITIZENS' READINESS TO USE E-ADMINISTRATION IN COMMUNES OF WEST-POMERANIAN VOIVODESHIP
}

\author{
AGNiESZKA AGATA TOMASZEWICZ
}

University of Szczecin, Faculty of Management and Economics of Services, POLAND

e-mail: agnieszka.tomaszewicz@wzieu.pl

\begin{abstract}
RECEIVED
ACCEPTED

6 November 2018

3 December 2018

JEL

CLASSIFICATION

D35, D38

KEYWORDS

e-administration, virtual community

ABSTRACT

The article presents the readiness of local communities to use e-administration solutions. The main aim of the article was to assess the level of e-administration implementation which was presented on the basis of the research conducted among the local communities of West-Pomeranian voivodeship. What decides about the readiness are the following; digital access, current infrastructure, availability of applied solutions, the customization of offices' web pages for local communities as well as obtaining skills by both citizens and clerks and willingness or need for using new type solutions.
\end{abstract}

\section{Introduction}

E-administration implementation requires application of ICT tools resulting in radical reconstruction of administration internal processes and the way of providing services. The result shall include opportunities to provide various services in more effective manner which would increase citizens' comfort. ICT implementation requires organizational changes, however, it is also conditioned by them. The changes regard the relation between 
e-administration subjects and customers, changes connected with purchasing new devices, application of new communication systems or procedural changes.

Considering all the above, in order to implement e-administration, obtaining the ICT skills seems the key factor. Thus, the aim of the article is to provide the level of local communities readiness regarding the use of public e-administration, particularly in the self-governing region meaning as it has a direct influence on the accurate use of e-administration solutions.

\section{Litepature review}

From the point of view of the citizens, frequently, the most vital body of public authority becomes local authority. It happens due to the tasks and citizen-like character of the governing bodies. It creates the possibility to keep real bond between public authorities and voters (Izdebski, 2003, p. 9). The basic unit of local authority is the commune which realizes public local matters also these which in accordance with the statute were not directed to any other subject (Filipek, 2003, p. 158; Art. 164 item. 3 RP Constitution, Art. 6 of the Ustawa z dnia 8 marca $1990 \mathrm{r}$...). The commune tasks mainly include the tasks which are of public utility character and their goal stipulated in the art.7 item 1 is 'current and continuous satisfaction of the collective population needs by means of providing commonly available services' (Ustawa z dnia 8 marca 1990 r...). In the view of information society it is natural that more and more of the tasks shall be realized via the Internet. Regarding such approach one may assume that the use of the ICT for providing services by public administration is called e-administration in the literature (Fiuk, 2009, p. 1). The given definition assumes that ICT technologies will become a catalyst for the expected changes in the country mainly in public administration (Rozporządzenie, 2006) and as for now on the basic indicator will constitute the level of availability and willingness to use public e-services provided by self-governance.

\section{Method}

The subject as well as the main area of research were local communities of West-Pomeranian voivodeship. They were subjected to the survey and communal offices of West-Pomeranian voivodeship which despite survey were subjected to the analysis of the web pages content of the West-Pomeranian voivodeship communes.

\section{Results}

The aim of the research was to assess the readiness to use public e-administration by local communities in communes of West-Pomeranian voivodeship. Thus, access to the Internet was assessed as the basic element influencing commonness of e-services which is more and more often treated as its universal law (Kaczmarek, 2005 , p. 340). Hence, a starting point for the analysis of e-administration area was defined to be the assessment of the level of new ICT technologies use, particularly the Internet. In Poland, in accordance with Social Diagnosis, it is estimated that in 2015 about $71 \%$ citizens had Internet access (in 2013 it was 66\%), including 70\% in WestPomeranian voivodeship assuming $10^{\text {th }}$ position among all voivodeships (Czapiński, Panek, 2015, p. 378; Czapiński, Panek, 2014, p. 332).

In the primary research, conducted for the needs of the accepted research area, the respondents declared a considerately higher, about $97 \%$, access to the Internet in their household while only $3 \%$ declared having no access. Additionally, $69 \%$ of the respondents claimed that the Internet access they are having currently in the 
commune fully satisfies their needs. The results obtained in the survey show that the majority of the citizens (69\%) are satisfied with the Internet access and only $1 \%$ claims that they do not need the Internet at all. The organizational units also state that the Internet access is sufficient. All the researched councils also showed that the Internet range encompasses the whole commune area.

The e-administration development is strictly conditioned by the Internet access among clerks. That is why, the councils were asked about the percentage of the clerks having the Internet access in their workplace. In the majority of the councils the level was not lower than $75 \%$. The remaining councils declared that the Internet access is between 50 and $75 \%$.

In self-governance times, a particular role shall be ascribed to communication between authorities and local communities considering its meaning in providing services adjusted to society needs. Therefore, aiming at general estimation of communities' interest in contact with e-administration, respondents were asked about the frequency of visiting councils' web pages in the communes they live in. The obtained results show that up to $91 \%$ citizens of West-Pomeranian voivodeship visited council's web page, including the biggest number $(65 \%)$ of respondents doing it few times a year. The results were presented in Figure 1.

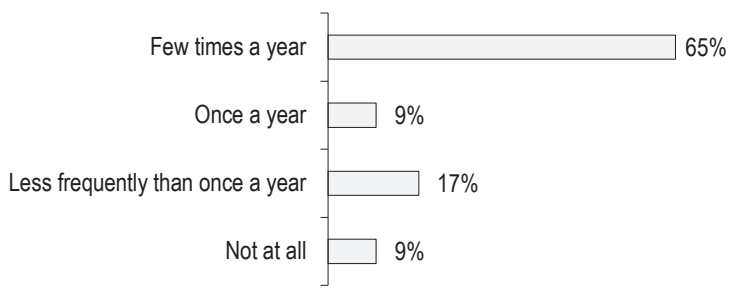

Figure 1. The frequency of council's web site visits in the inhabited commune

Source: own elaboration on the basis of the survey research of the local communities in West-Pomeranian voivodeship.

A considerate interested in communes' websites may be somewhat treated as a sign in favor of e-administration development as only $9 \%$ of the respondents have not visited the website of their commune at all.

The Communication between administration and society may be held also through providing information only. That is why the respondents were asked to provide answer if they were looking for information on dealing with official matter on the web sites (public services). Determining the level of interest in looking for information may indirectly serve as a mean to assess potential demand regarding realization of official matters. $83 \%$ of the respondents admitted that they were looking for such information. Similar values were provided in the report by the Ministry of Administration and Digitalization "E-administracja w oczach internautów - 2016" (p. 15). The percentage of these who were looking for the information in 2016 was given in the document as of $86 \%$ (increase for 4 percentage points in comparison with 2013 (E-administracja w oczach internautów - 2013, p. 15).

Besides providing access to information, it is also vital that providing information should be not only up to date but also clear for the recipients. According to the very same report of the Ministry of Administration and Digitalization as of 2016 (p. 17), the information presented on the West-Pomeranian councils web sites was found clear for $85 \%$ of the researched persons. 
The conducted survey enabled estimating the number of people using the Internet while dealing with official matters. ${ }^{1}$

Marginal majority of the respondents (53\%) admitted that they have not used the Internet while dealing with official matters however these who did use it was about $47 \%$ in West-Pomeranian voivodeship. The respondents using the Internet for the above purpose were also asked to indicate the web site they used most frequently. The biggest number of the citizens indicated the given council's webpage $(57 \%)$, next page was BIP (35\%) and only $5 \%$ of the respondents used ePUAP (Electronic Platform for public administration services). Popularity of the particular websites may be explained with its ease-of-use or functionality. About $76 \%$ of the persons using the Internet in order to realize the official matter did it in traditional way previously, so they went to the council to do so. For about a quarter of the respondents, the Internet became a basic tool for searching the information on the official matters.

Public administration availability on the Internet enables the content transfer, downloading information or forms. Therefore, the respondents were asked about downloading the electronic forms from the websites in the last three months. From the respondents using the websites for realization of official matters, about $69 \%$ gave a positive answer which may be perceived as a good sign for further interest in e-administration.

In the following analysis of the conducted research on the frequency of realizing official matters in the council, it is shown that $82 \%$ of the respondents, once or more in the last year realized such an official matter. The biggest number of people did it from 2 to 3 times $(35 \%)$.

The data is presented in Figure 2.

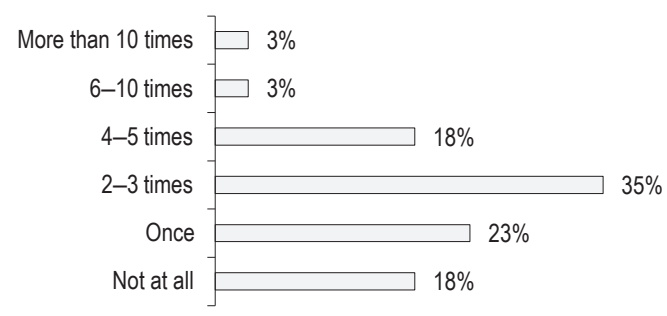

Figure 2. The frequency of realizing official matters in councils in the last year

Source: own elaboration on the basis of survey conducted among local communities in West-Pomeranian voivodeship.

The respondents were also asked about the percentage of the matters realized via the Internet (the obtained data is presented in Figure 3).

\footnotetext{
${ }^{1}$ Realising official matters shall be seen as every activity connected with managing official matters regardless of the stage, excluding looking for information which was presented above so mainly it shall encompass downloading documents and forms template or possible sending them to the councils.
} 


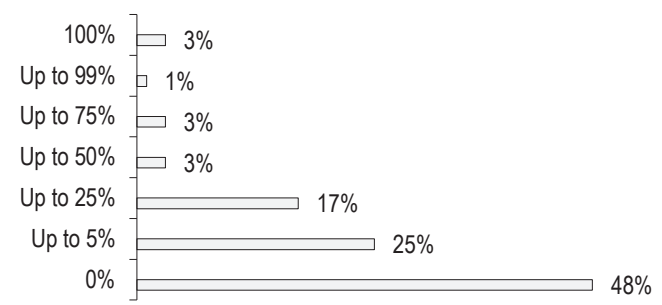

Figure 3. The percentage of the official matters realized via the Internet in comparison with all matters according to local communities

Source: own elaboration on the basis of survey conducted among local communities in West-Pomeranian voivodeship.

Among people who realized official matters, about one fourth of the citizens determined this role for up to $5 \%$ and further $17 \%$ of the respondents stated that the number of matters realized on the Internet in comparison to the general number of matters equaled $25 \%$. Among about $3 \%$ of the respondents, the percentage was as high as $100 \%$ which means that they realized all the official matters only on the Internet. However, according to data collected they realized only one matter.

About half of the respondents claimed that the meaning of the role of the matters handled via the Internet in comparison to all matters is none. These could be both respondents who did not use the Internet to deal with official matters or the respondents who did not deal with any official matters at all nor on the Internet or in the traditional manner. As the collected data show, communities from West-Pomeranian voivodeship use the Internet only to a small extent meaning that they prefer traditional way of handling official matters.

In accordance with the amendment to the Act on activities of the entities performing public tasks, delivering a notice via electronic means requires filing an application in the form of electronic document via inbox electronic mail having ePUAP standards. In order to file such an application one shall have a digital signature (Art. 16 item. 1a; Art. 39 § 1 Ustawa z dnia 10 stycznia 2014 r. o zmianie ustawy o informatyzacji podmiotów realizujacych zadania publiczne oraz niektórych innych ustaw, Art. 63 §3a point 1 Obwieszczenie). A digital signature is regarded as a safe profile $^{2}$ which constitutes a form of electronic way of identification for users willing to use this kind of communication with a council by means of inbox electronic mail.

In case of entrepreneurs, using e-administration next to the ePUAP safe profile is also enabled with a qualified digital signature ${ }^{3}$ (Art. 3 point 14 of the Ustawa z dnia 17 lutego 2005 r. o informatyzacji działalności podmiotów realizujacych zadania publiczne).

One May assume that theoretically persons (meaning these persons who are not required to provide an additional exhibits in council in person) who fully may handle an official matter via the Internet are these who possess the safe profile or qualified digital signature. Hence, having a ePUAP safe profile is a necessary condition for citizens who want to fully realize an official matter via electronic way. Thus the number of the ePUAP safe

${ }^{2}$ A Safe profile is a free of charge alternative for safe Digital signature which is verified with valid qualified certificate (www.epuap. gov.pl). In accordance with the statute a safe ePUAP profile is a 'set of information identifying and describing a subject Or a person being a user of ePUAP account which was checked in a reliable way by the entity stipulated in art. 2'.

${ }^{3}$ A safe profile May be obtained only by a natural person however s/he May complete the profile s/he already Has with the data of his/her entrepreneur (http://www.epuap.gov.pl). 
profiles may be included in the meters indirectly influencing the evaluation of local e-administration condition. The communities in West-Pomeranian voivodeship were asked about safe profiles. The results are presented in the Figure 4.

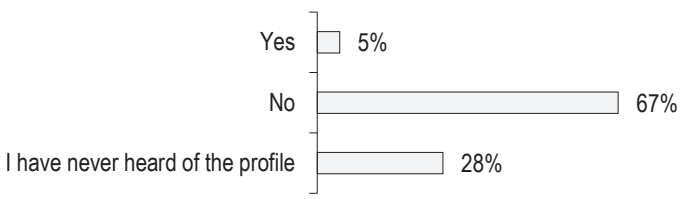

Figure 4. The percentage of persons having the safe profile in West-Pomeranian voivodeship

Source: own elaboration on the basis of the survey among local communities in West-Pomeranian voivodeship.

In the voivodeship, about $5 \%$ of the respondents declare having the safe profile. Regarding all the above mentioned conditions, it may be assumed that theoretically only this minor percentage of the citizens is able to fully realize an official matter via electronic way, that is without going to the council in person. The notion of the 'safe profile' is not commonly known to citizens of West-Pomeranian voivodeship yet. Still, about $28 \%$ of the respondents has never encountered such notions. Being familiar with the safe profile (72\% of the respondents), among WestPomeranian voivodeship communities taking part in the research, is considerably higher from the one presented in the Ministry of Administration and Digitalization report 'E-administracja w oczach internautów - 2016' (p. 52). The report says that in West-Pomeranian voivodeship in 2016, the safe profile was encountered only by $47 \%$ of the citizens. Across the whole country regarding familiarity with the safe profile, about $1 \%$ less of the Poles admitted not being familiar with the notion.

The variety of the local e-administration level depends on a vast set of factors. One of them, conditioning the use of e-administration, including electronic services is the ability to use ICT tools, such as computer or the Internet. This condition regards both parties participating in the process, thus both the customers and the clerks and it constitutes one of the basis for e-administration development, because lack of the ability to use services in the information society in addition to the lack of access to electronic communication services is the main reason for social exclusion (Budziewicz-Guźlecka, 2010, pp. 241-249). In accordance with the report published by the Ministry of Administration and Digitalization, the citizens of West-Pomeranian voivodeship are the most confident as long as obtained ICT skills are considered among all the voivodeships (E-administration from the perspective of surfers2013 , p. 15). The conducted research, however, shows that about $79 \%$ of the respondents positively assess their ICT skills including the biggest number of $47 \%$ assessing their skills as rather very good. Additionally, the research depicted the subjects which use the Internet while realizing official matters and evaluate their skills on very high or rather high level, constituting $89 \%$ of all users.

\section{Conclusions}

As it is shown in e-administration, the success of e-administration development mostly depends on wide access of high-speed Internet, effective and friendly public e-services and constantly increasing digital skills of the society. Currently, society's level of readiness in particularly low as far as realization of the official matter on 
the Internet is considered, which in turn is highly influenced by low advance level. Further development of public e-services and trainings within the scope of its use and accurate architecture of ICT systems providing high usability and functionality of the councils' websites shall positively influence the development of the e-administration in West-Pomeranian voivodeship communes. However, one shall bear in mind that ICT Technologies shall be implemented only when they may be used effectively and it requires a previous ensuring that the level of users' ICT skills is high.

\section{References}

Budziewicz-Guźlecka, A. (2010). Istota wykluczenia społecznego w społeczeństwie informacyjnym. Prace Naukowe Uniwersytetu Ekonomicznego we Wrocławiu. Informatyka Ekonomiczna, 17 (118), 241-249.

Czapiński, J., Panek, T. (2014). Diagnoza społeczna 2013. Warunki i jakość życia Polaków. Warszawa: Drukarnia Braci Grodzickich Sp.J.

Czapiński, J., Panek, T. (2015). Diagnoza społeczna 2015. Warunki ijakość życia Polaków. Warszawa: Rada Monitoringu Społecznego. E-administracja w oczach internautów - 2013 (2013). Ministerstwo Cyfryzacji, PBS - Partner in Business Strategies. Warszawa.

E-administracja w oczach internautów - 2016 (2016). Ministerstwo Cyfryzacji, PBS - Partner in Business Strategies. Sopot.

Filipek, J. (2003). Prawo administracyjne. Instytucje ogólne. Część I. Kraków: Zakamycze.

http://www.epuap.gov.pl.

Izdebski, H. (2003). Samorząd terytorialny. Podstawy ustroju i działalności. Warszawa: Wydawnictwo Prawnicze LexisNexis sp. z 0.o.

Kaczmarek, T. (2005). Struktury terytorialno-administracyjne i ich reformy w krajach europejskich. Poznań: Wydawnictwo Naukowe UAM.

Fiuk, G. (ed.) (2009). Koncepcja rozwoju usług społeczeństwa informacyjnego Województwa Zachodniopomorskiego. Projekt "e-Zachodniopomorskie" - aplikacje i e-usługi, wrzesień. Retrieved from: http://www.zrsi.szn.pl/files/ezachodniopomorskie.pdf.

Obwieszczenie Marszałka Sejmu Rzeczypospolitej Polskiej z dnia 7 grudnia 2012 r. w sprawie ogłoszenia jednolitego tekstu ustawy o informatyzacji działalności podmiotów realizujących zadania publiczne. Dz.U. 2013, poz. 235.

Rozporządzenie Rady Ministrów z dnia 1 sierpnia 2006 r. w sprawie Planu Informatyzacji Państwa na rok 2006.

Ustawa z dnia 8 marca 1990 r. o samorządzie gminnym. Dz.U. 2001, nr 142, poz. 1591 ze zm.

Ustawa z dnia 17 lutego 2005 r. o informatyzacji działalności podmiotów realizujących zadania publiczne. Dz.U. 2013, poz. 235, 2014, poz. 183.

Ustawa z dnia 10 stycznia 2014 r. o zmianie ustawy o informatyzacji podmiotów realizujących zadania publiczne oraz niektórych innych ustaw, Dz.U. poz. 183.

Cite this article aS: Tomaszewicz, A.A. (2018). Citizens' readiness to use e-administration in communes of West-Pomeranian voivodeship. European Journal of Service Management, 4 (28/1), 329-335. DOI: 10.18276/ejsm.2018.28/1-41. 